\title{
Parental Bereavement Following the Death of an Adult Child
}

\author{
Allan E. Crandell, MD \\ Thomas Jefferson University Hospital
}

Follow this and additional works at: https://jdc.jefferson.edu/jeffjpsychiatry

Part of the Psychiatry Commons

Let us know how access to this document benefits you

\section{Recommended Citation}

Crandell, MD, Allan E. (1985) "Parental Bereavement Following the Death of an Adult Child," Jefferson Journal of Psychiatry. Vol. 3 : Iss. 1 , Article 6.

DOI: https://doi.org/10.29046/JJP.003.1.003

Available at: https://jdc.jefferson.edu/jeffjpsychiatry/vol3/iss1/6

This Article is brought to you for free and open access by the Jefferson Digital Commons. The Jefferson Digital Commons is a service of Thomas Jefferson University's Center for Teaching and Learning (CTL). The Commons is a showcase for Jefferson books and journals, peer-reviewed scholarly publications, unique historical collections from the University archives, and teaching tools. The Jefferson Digital Commons allows researchers and interested readers anywhere in the world to learn about and keep up to date with Jefferson scholarship. This article has been accepted for inclusion in Jefferson Journal of Psychiatry by an authorized administrator of the Jefferson Digital Commons. For more information, please contact: JeffersonDigitalCommons@jefferson.edu. 


\title{
PARENTAL BEREAVEMENT FOLLOWING THE DEATH OF AN ADULT CHILD
}

\author{
ALLAN E. CRANDELL, M.D.
}

\section{INTRODUCTION}

To coin a title with the words "death" and "children" in it appears to me like the height of incongruity. Children are like definitions of life itself. They seem to bubble over and to foam with vitality. Life seems to be theirs, even the sickly and skinny ones, and death is the property of the old. Children have sparkling eyes and uncomplicated ways and innocence and a simplicity I envy. I am temporarily tempted to keep the little ones that way. I think of joining parents and educators who struggle to spare them from any ugliness in their world, especially the ugliness in human death (1).

This unfamiliar juxtaposition of children and death by Robert Kavanaugh is the basis for this case report and discussion. Death as a subject, and dying as a process to be studied, are areas of research that have only recently become prominent. The number of scientific and academic articles about death has risen from about twenty a year in the 1940's to several hundred per year in the 1970's (2). Bereavement remains, however, in some ways a neglected area of research (3). Now the task seems to be not simply to appreciate grief and mourning as species-wide human activities, but to begin to parse out the difficulties associated with specific types of death and dying, as well as the attributes or limitations of those who mourn.

\section{CASE REPORT}

A pale, frail, elderly-appearing woman presented herself to a hospital crisis center with the chief complaint, "My son was murdered." She was a fifty-seven-year-old divorced woman who was working in a local restaurant as a prep cook. She lived in her own home with her eldest son, her third son and his wife. She had survived several difficult periods in her life having to do with her husband's infedility and alcohol abuse, and her eldest son's chronic psychotic illness.

The patient's problems with coping began four months prior to presentation, when her youngest son was apparently murdered. Briefly, her son had been found in a local river on Good Friday. Two males had been accused in his death. The patient stated that she had not made much progress in beginning the grief process. She complained of low energy, being "uptight," frequent crying spells, guilt over her son's death, problems at work, and ambivalence about visiting the gravesite. An additional stressor was her

Dr. Crandell is Chief Resident, Department of Psychiatry, University of Vermont. 
belief that other family members, particulary the surviving siblings, had been better able to deal with her son's death. She also mentioned that other family members appeared cruel and uncaring in relating to her eldest, schizophrenic son.

The patient's past psychiatric history was essentially unremarkable, except for a few crisis center visits about five years earlier relating to marital problems and the late-emerging illness of her eldest son. A social history revealed that she had been born in a small town in Vermont and had spent her entire life in the state. Her father was a road commissioner prior to his retirement, but was still active at the age of eighty-three. Her mother died from breast cancer several years previously. Her family lived on a farm during her youth. She finished high school. Family history was unremarkable psychiatrically, except for the aforementioned schizophrenic illness of her eldest son and a grandchild with mild mental retardation. She had a total of six children.

Mental status on initial presentation revealed a slightly dishevelled woman looking appreciatively older than her stated age. She was in moderate distress. She sat quietly throughout the interview with a minimum of spontaneous movement, occasionally crying and speaking very softly. She appeared to have very little energy, but displayed an appropriate affect that was sad, but restricted. Her thought processes were coherent; her thought content was remarkable only for her persistent preoccupation with her son's death and its details, e.g., gravesite, legal matters, etc. Her insight was moderately good, except in regard to the grieving process. She was oriented times three, had no cognitive deficits, was judged to be of average intelligence, and denied suicidality.

The initial assessment was that the patient was suffering from a prolonged grief reaction. There were also elements suggestive of a major depressive episode. Because of her apparent inability to cope with her son's death, a short inpatient stay was suggested. The patient refused to be hospitalized. An attempt was made to treat her symptoms of depression with amitriptyline, but this medication trial was discontinued secondary to complaints of oversedation. Her treatment eventuated in weekly visits for outpatient psychotherapy with a psychiatric resident. The initial focus of her outpatient treatment was seen to have three elements:

a) To facilitate beginning of her grief work;

b) To help her in dealing with her eldest son and his continuing dependency needs; and

c) To begin supportive psychotherapy as she approached and dealt with the exigencies provoked by the upcoming trials of the accused.

In a videotape made approximately a year-and-a-half after the death of her son, the patient was able to examine her progress in mourning. There were significant elements of anger that had abated somewhat. This anger consisted either of anger turned inwards insofar as she felt guilty about her son's death; or anger that she was able to express as blame directed towards the courts, the conduct of the trials, and society itself. She was able to say that there had been a gradual dimunition of anger and guilt over the previous year-and-a-half. She was, however, still in touch with both 
emotions, and at times remained very close to tears. Most of her depressive neurovegetative symptoms had disappeared, and she was once again able to work effectively and conduct her daily affairs with a sense of satisfaction and pleasure.

If anything, the patient had become even more concerned about the behavior and day-to-day conduct of her schizophrenic son. This concern was manifested by her social altruism. She became very active in the politics of self-help groups for families who have mentally ill members. It was also noted during her outpatient treatment that she had become concerned about her grandson, who had recurrent problems in controlling his serum glucose. Although she judged herself ready to terminate outpatient psychotherapy, her overwhelming feeling was that she would never, in fact, get over the death of her son.

\section{DISCUSSION}

An obvious question that arises in consideration of the above case is what constitutes the "normal" grief process? Clayton (4) noted a three-part description of normal grief consisting of:

a) A period of numbness which could last from days to weeks;

b) A period of recoil or depression which could last from a few weeks to a year; and

c) Eventual recovery.

Clayton also suggested that the death of a child is the most significant and traumatic death of any family member. Brown and Stoudemire (5) identified three equivalent categories of the grief process. Phase One, which is the period of shock, begins immediately after the loss and lasts from one to fourteen days. Phase Two involves preoccupation with the deceased, is well-developed by three weeks, and can last up to six months. Resolution encompasses Phase Three, wherein the bereaved becomes able to recall past events with pleasure, regains interest in activities, and begins making new social contacts.

Pathological grief, on the other hand, was thought by Brown and Stoudemire to be influenced by four factors:

a) Characteristics of the survivor;

b) Circumstances surrounding the death itself;

c) Relationship before the death; and

d) Survivor's social/family support system.

Pathological grief can consist of two forms: delayed grief, a protracted delay or even totally absent grief; and distorted grief, which is manifested by persistent compulsory overactivity without an accompanying sense of loss, identification with the deceased, deterioration of the survivor's health, social isolation, and severe depression. These distorted or abnormal grief responses have also been mentioned by Kavanaugh (6), who said they can be expressed as a delayed response, adverse reactions, major psychosis, substitution (wherein the mourner takes over the deceased's illness), 
psychosomatic illness, or introjection of the characteristics of the deceased. With regard to the case described, the difficulties inherent in deciding whether or not a particular grieving process is pathological is clear. At the time of presentation, the patient described herself as "numb," but there was evidence of later stages of grieving as well, e.g., her symptoms of depression. In this case, since the patient presented approximately four months after the death of her son, there did seem to be a protracted delay in mourning that could be characterized as pathological grief.

Perhaps the most well-known categorization of responses to impending death are those enumerated by Kubler-Ross (7). Her stages of denial, anger, and guilt were clearcut features in the case described. What the patient did not have available were the possibilities of preparatory grief or a "goodbye" stage. The patient also exhibits several of the stages noted by Kavanaugh (1) in that she did progress through periods of shock, disorganization, and volatile emotions; moreover, a sense of guilt permeated her initial presentation and subsequent psychotherapy. Feelings of loss and loneliness were also apparent, but Kavanaugh's final two stages of a sense of relief and the reestablishment of a stable existence are harder to discern in this patient.

There has been some criticism of what could be called "stage theories" that have been described. Bugen (7) believed that such stages are not separate entities, but subsume one another or blend dynamically. He also stated his belief that these stages need not be successive and that it is not necessary to experience every stage. He notes that the intensity and duration of any stage may vary idiosyncratically among those who grieve and charges that there is little empirical evidence to support such stages. $\mathrm{He}$ proposes that it is the interaction of the survivor's closeness to the deceased and the perception of the predictability of death that are more reliable predictors of grief. If the relationship to the deceased is a central one and the death was seen as preventable, then he suggests that grieving will be intense and prolonged. Conversely, if the relationship was a peripheral one, and the death was perceived to have been unpreventable, then he suggests that the grieving process may be milder and less prolonged. Therefore, positive movement consists of lessening feelings of responsibility and guilt, and changing what was formerly a central relationship to one that is more peripheral.

Levav (3) notes that there is surprisingly little research considering the intense and prolonged suffering that seems to accompany the death of an adult child. His 1982 review of the literature notes that very few studies have been done in this area. $\mathrm{He}$ criticizes these on methodological grounds with regard to the number of subjects, lack of controls, insufficient duration of the grieving process studied, and the fact that most involve spouses and not grieving parents. The size of the potential survivors' population can be inferred from statistics that indicate that child homicide in 1982 was one of the five leading causes of death for all persons age one to seventeen (9). The same source notes that since 1925 homicide rates have increased sixfold for persons one- to four-years-old and twofold for persons five- to fourteen-years-old. Rates have been peaking for infants and teenagers. From 1976 to 1979, nine per cent of homicide victims reported to the FBI were less than eighteen years old. The phenomena of violent death led Burgess (10) to formulate what she called the "homocide-trauma syndrome." This syndrome consists of both a crisis and a subsequent bereavement 
phase. She divided the crisis phase into the acute grief reaction and the acute reaction to homocide, the latter involving funeral details and prolonged police contact with lack of closure. She believes that the long-term resolution of this syndrome will lead to grief work being done. However, she divides the process into psychological issues and psychosocial issues. Psychological issues include settling "if only" dilemmas, recurrence of dreams and nightmares, development of phobias, various types of identifications with the tragedy itself, and role changes for the bereaved. Psychosocial issues involve the court process itself, and blame or projection onto the courts, police, and even the victim. Blaming the victim may be a result of the belief that the victim precipitated or in some way participated in his or her death. Sanders (11) studied seventy-six women and twenty-six men who lost children. Based on the fact that child death in the modern age is rare and therefore unexpected, she found significant evidence of grief in parents surviving a child's death. This grief was manifested by depression, anger, guilt, despair, and the perceived impossibility of surviving one's own child. She did not find any differences in bereavement intensity between those who survived a chronic-illness-death versus sudden death.

Viedeka-Sherman (12), in a Chicago study of self-help groups, arranged coping strategies from the least to most adaptive in looking at 194 parents immediately and one year after bereavement. The least adaptive strategies were found to be attempts to deny the death of the child and preoccupation with the deceased child. Persisting preoccupation with the child was seen as equivalent with persisting depression. More adaptive coping strategies were seen to be active and externally directed. Externally directed strategies might involve replacement of the child either literally, as in pregnancy or adoption, or figuratively, as in the development of altruistic concerns. This certainly relates to the patient described, who was able to develop more adaptive coping strategies. She gave up trying to deny the death of her child, immersed herself in work, surrendered her preoccupation with him, and was able to develop altruistic concerns.

In examining parents as survivors, a number of unanswered questions arise. It does seem that bereavement of a parent is an area that has not been adequately explored, and that the death of a child might require grief work that is qualitatively different from that required by the death of a parent or spouse. Of additional interest is whether or not the acute, unexpected, or violent death of a child is different in terms of its impact on the grieving process than a child's death that is due to long term illness. The presentation of a bereaved parent, that is to say, how and where in the social and/or medical system they appear, is important. Additional interest should be focused on whether or not the medical-legal system helps to isolate survivors of those who have been murdered.

The ultimate value of exploring how parent-survivors cope with the death of their children is its potential to enhance our understanding of the grief process. The essential task, as Lindemann (13) concisely expressed, is to actively share in the grief work of our patients. We can only speculate on how surviving parents can ever fully absorb or integrate the death of a child, especially if that death has been violent, acute, or 
unexpected. Perhaps we must concur with Gorer that:

The most distressing and long-lasting of all griefs, it would seem, is that for the loss of a grown child. In such a case it seems to be literally true and not a figure of speech, that the parents never get over it (14).

Bereavement of parents as a process remains one of the most complex, universal, and yet elusive of human responses to stress. It qualifies as an engaging and potentially rich field for further study.

\section{REFERENCES}

1. Kavanaugh E: Facing Death. New York, Penguin Books, 1972

2. Fulton R: A bibliography on death, grief, and bereavement. Volumes I, 1845-1975, and II, 1975-1980

3. Levav I: Mortality and psychopathology following the death of an adult child: an epidemiological review. Isr J Psych Rel Sci 19:23-38, 1982

4. Clayton PJ: Bereavement, in A Handbook of Affective Disorders. Edited by Paykel ED. Edinburgh, Churchill Livingstone, 1982

5. Brown J, Stoudemire G: Normal and pathological grief. JAMA 250:378-382, 1983

6. Cavenar JO, Burns T, Spauling JG: Grief: normal or abnormal. NC Med J 39:31-34, 1978

7. Kubler-Ross E: On Death and Dying. New York, MacMillan, 1969

8. Bugen A: Human grief: a model for prediction and intervention. Am J Orthopsych 47:196-206, 1977

9. MMWR: Child Homocide in United States 31:292-294, 1982

10. Burgess A: Family reaction to homocide. Am J Orthopsych 45:391-398, 1975

11. Sanders M: A comparison of adult bereavement in the death of a spouse, child, and parent. Omega 10:303-322, 1979-80

12. Viedeka-Sherman L: Coping with the death of a child: a study over time. Am J Orthopsych 52:688-698, 1982

13. Lindemann E: Symptomatology and management of acute grief. Am J Psych 101:7-21, 1944

14. Gorer G: Death, Grief, and Mourning. London, Cresset Press, 1965 